\title{
BMJ Open Changing trends in nutritional status of adolescent females: a cross-sectional study from urban and rural Bangladesh
}

\author{
Ishita Mostafa (D) , ${ }^{1}$ Mahamudul Hasan, ${ }^{1}$ Subhasish Das (D) , ${ }^{1}$ \\ Soroar Hossain Khan, ${ }^{1}$ Md lqbal Hossain, ${ }^{1,2}$ Abu Faruque, ${ }^{1}$ Tahmeed Ahmed (i) 1,2,3
}

To cite: Mostafa I, Hasan M, Das S, et al. Changing trends in nutritional status of adolescent females: a crosssectional study from urban and rural Bangladesh. BMJ Open 2021;11:e044339. doi:10.1136/ bmjopen-2020-044339

- Prepublication history and supplemental material for this paper is available online. To view these files, please visit the journal online (http://dx.doi. org/10.1136/bmjopen-2020044339).

Received 01 September 2020 Revised 26 January 2021 Accepted 26 January 2021

Check for updates

(c) Author(s) (or their employer(s)) 2021. Re-use permitted under CC BY-NC. No commercial re-use. See rights and permissions. Published by BMJ.

${ }^{1}$ Nutrition and Clinical Services Division, International Centre for Diarrhoeal Disease Research

Bangladesh, Dhaka, Bangladesh

2James P. Grant School of

Public Health, BRAC University,

Mohakhali, Dhaka, Bangladesh

${ }^{3}$ Department of Global Health,

University of Washington,

Seattle, Washington, USA

Correspondence to

Dr Ishita Mostafa;

ishita.mostafa@icddrb.org

\section{ABSTRACT}

Objectives Malnutrition remains a major problem among adolescents worldwide, but the types of nutritional problem impacting this group are changing significantly. This study aims to describe and analyse the trends in nutritional status and related epidemiological characteristics of 10 to 19 years old adolescent girls over time (2001 to 2018) in Bangladesh.

Methods We extracted data from the Diarrhoeal DiseaseSurveillance System of the International Centre for Diarrhoeal Disease Research Bangladesh. We performed $\chi^{2}$ test for trend to test for statistical significance of the changing trends of undernutrition and overnutrition among the study participants. Multivariable logistic regression model was fit to measure the strength of association, reported as adjusted OR (aOR) and corresponding 95\% Cls. Results A total of 1224 and 628 adolescent females attended urban and rural treatment facilities, respectively, between 2001 and 2018. The proportion of stunting and thinness decreased substantially, whereas overweight has been observed to increase $(1.7 \%$ to $7.4 \%, \mathrm{p}<0.001)$ over the study period. Factors independently associated with stunting were illiteracy (aOR $2.39,95 \% \mathrm{Cl}$ (1.68 to 3.39), $p<0.001)$, monthly family income of less than US\$100 (a0R $1.54,95 \% \mathrm{Cl}(1.25$ to 1.9$), \mathrm{p}<0.001)$ and family belonging to poorest wealth quintile $(\mathrm{aOR} 1.45,95 \% \mathrm{Cl}$ (1.13 to 1.87), $\mathrm{p}=0.004)$. Younger participants ( $\mathrm{aOR} 2.69$ $95 \% \mathrm{Cl}(2.10$ to 3.45$), \mathrm{p}<0.001)$, rural participants (aOR $1.7195 \% \mathrm{Cl}(1.23$ to 2.38$), \mathrm{p}<0.001)$, longer hospital stay (aOR $1.52,95 \% \mathrm{Cl}$ (1.16 to 1.98), $\mathrm{p}=0.002$ ) and monthly family income less than US\$100 (aOR 1.44, 95\% Cl $(1.09$ to 1.89 ), $p=0.009$ ) were significantly associated with thinness. Conversely, overweight/obesity was associated with monthly family income more than US $\$ 100$, duration of diarrhoea and rural participants.

Conclusion Undernutrition in adolescent girls has decreased with time, but the burden of overweight has increased. Higher literacy and better wealth status were found to be associated with the improved nutritional status of the participants.

\section{INTRODUCTION}

Nutrition is a basic human need and prerequisite for a healthy life. Adequate nutrition is indispensable in every phase of life, and adolescence is the only time in life besides early infancy when the velocity of growth

\section{Strengths and limitations of this study}

- A strength of the study is that we have followed an unbiassed systematic sampling of patients seeking diarrhoeal treatment.

- Most of the surveys reported on adolescent girls studied those aged 15 years or older. Our study has included adolescent girls of aged 10 to 19 years as defined by WHO.

- A limitation is that we used Body Mass Index (BMI) as the only measure of overweight. BMI does not distinguish between body fat and lean body mass. However, BMI is a WHO-prescribed indicator of nutritional status measurement that is internationally accepted.

- The analyses described were limited by the availability of information and may not be nationally representative.

increases. ${ }^{1}$ The WHO defines adolescents as individuals in the 10 to 19 years age group. ${ }^{2}$ In girls, more than 20 per cent of adult height is attained and up to 50 per cent of adult weight is gained in adolescence. During this age period, poor nutrition affects adult body size, which results in shortness or thinness. ${ }^{3}$ On the other hand, over nutrition in adolescents is associated with chronic disease and mortality in later part of life. ${ }^{4}$ During adolescence, optimum nutrition puts an added importance on women's health as it is relevant to maternal nutrition. Adolescent pregnancy poses substantial risks for maternal and infant outcomes. ${ }^{5}$ Furthermore, pregnancy in adolescence will slow and stunt a girl's growth, ${ }^{6}$ reinforcing the 'intergenerational cycle' of malnutrition.

The double burden of malnutrition is the coexistence of overnutrition and undernutrition at all levels of the population. In low-income and middle-income countries, undernutrition and overnutrition are co-occurring among different population groups, and the driving force behind the shift is rapid increase in economic development, 
globalisation and urbanisation, leading to tremendous changes in lifestyle mainly by changes in diet and physical activity. ${ }^{7}$ The phenomenon is also present among the adolescents. In some countries, nearly half of all adolescents are stunted, which means their physical and cognitive development has been restricted because of inadequate nutrition. ${ }^{8}$ South Asia reports the highest prevalence of underweight. Overweight or obesity (Body Mass Index Z score (BMI Z) $>2$ ) is also highly prevalent in many regions, for example, Latin America and the Caribbean have the highest regional prevalence of overweight in both rural and urban settings among the adolescents. ${ }^{9}$ As for Bangladesh, malnutrition in adolescents has been a major public health problem over the years. There are about 29.5 million adolescents in Bangladesh and about 14.4 million of them are girls, which makes up nearly onefifth of the total population. ${ }^{10}$

According to Bangladesh Demographic and Health Survey (BDHS) 2014, 31 per cent of 15 to 19 years aged adolescent girls are undernourished $(\mathrm{BMI}<18.5)$ in the country. ${ }^{11}$ Previous demographic health surveys have also reported the nutritional status of 15 to 19 years old adolescent females but, except BDHS 2004, but none of the surveys reported about 10 to 14 years age group. So, there is limited evidence on changing trends of nutritional status of adolescent girls 10 to 19 years old over the years and any observed urban-rural differentials in these changing trends. Hence, the present study was conducted to measure the changing trends in nutritional status and any linked epidemiological characteristics using the recommended anthropometric indicators in the rural and urban community in Bangladesh. Exploring the differences and associated risk factors could provide policy makers with a great platform for implementing nutrition interventions for this vulnerable population.

\section{METHODS}

\section{Study setting and source of data}

Data for this analysis was extracted from the Diarrhoeal Disease Surveillance System (DDSS) of the International Centre for Diarrhoeal Disease Research, Bangladesh (icddr,b). It has been providing care and treatment to a large number of patients for a long period of time. icddr,b has two diarrhoeal disease treatment facilities: one in urban Dhaka (Dhaka Hospital) and the other in rural Matlab (Matlab Hospital). icddr,b established the DDSS at the Dhaka Hospital in 1979, which systematically sampled $2 \%$ of all patients since 1996 . This system collects information such as age, sex and socio-demographic status, clinical characteristics and aetiology of diarrhoea among presenting patients. The Matlab Hospital DDSS is part of a larger Health and Demographic Surveillance System (HDSS) created in Matlab subdistrict, a rural area in east-central Bangladesh, in 1966. The rural Matlab Hospital enrolled all patients coming from icddr,b HDSS area. The database of DDSS also has information on the nutritional status of this patient population, including that of adolescent females that allows analysis of trends over the decades. For the present study, relevant information of adolescents coming to treatment facility each year were collected and a total of 1852 adolescent girls (1224 at urban site and 628 at rural site) aged 10 to 19 years was extracted from the DDSS for the period of 2001 to 2018. Details of year-wise samples are provided in online supplemental file 1. Adolescent girls were enrolled in the DDSS irrespective of their socio-economic status (SES) and disease severity in both hospitals.

\section{Assessment of nutritional status}

Anthropometric measurements of adolescent females (height and weight) were recorded. Weight was measured to the nearest $100 \mathrm{~g}$ using a digital scale, and height was determined using a locally constructed height scale with a precision of $2 \mathrm{~mm}$. Trained research assistants performed all nutritional status measurements following standard procedures. ${ }^{12}$ These measurements were subsequently compared with the WHO 2007 growth standards at the time of data analysis.

\section{Definitions}

Provided in table 1 .

\section{Data analysis}

Data were analysed using Statistical Package for Social Sciences (SPSS) Windows (V.20.0; Chicago, Illinois) and Epi Info (V.7.0, USD, Stone Mountain, Georgia). Characteristics of the study population were described as percentages. Principal component analysis (factor analysis) was performed to determine wealth quintiles (by using household assets) for each time point separately for each site, assuming that factor loadings for certain

Table 1 The definitions of stunting, severe thinness, thinness, overweight and obese indices were based on the WHO guidelines

\begin{tabular}{|c|c|}
\hline Nutritional status & Definition by WHO \\
\hline Stunting & $\begin{array}{l}\text { Height-for-age Z score (HAZ) } \\
<-2.00 \mathrm{SD}\end{array}$ \\
\hline Severe thinness & $\begin{array}{l}\text { Body Mass Index-for-age Z } \\
\text { score (BAZ) <-3.00 SD }\end{array}$ \\
\hline Thinness & $\begin{array}{l}\text { Body Mass Index-for-age Z } \\
\text { score }(B A Z)<-2.00 \mathrm{SD}\end{array}$ \\
\hline Overweight & $\begin{array}{l}\text { Body Mass Index-for-age } Z \\
\text { score }(B A Z)>+1.00 \text { SD }\end{array}$ \\
\hline Obese & $\begin{array}{l}\text { Body Mass Index-for-age } Z \\
\text { score }(B A Z)>+2.00 \text { SD }\end{array}$ \\
\hline Other conditions & Definitions used in the study \\
\hline Illiteracy & Having no formal education \\
\hline Income & $\begin{array}{l}\text { Cumulative monthly income } \\
\text { of household head (father) } \\
\text { and also mother; this was } \\
\text { converted into US\$ by dividing } \\
\text { the monthly income by year- } \\
\text { specific conversion rate of US\$ }\end{array}$ \\
\hline
\end{tabular}


household assets may vary through the years, in ascertaining the overall trend and association with nutritional status at different points of observation. We performed the $\chi^{2}$ test for trend to test for statistical significance in changing trends and used trend lines for understanding the direction of the changing trends of nutritional status. Percentage reduction was calculated by subtracting the first observation point from the last one, divided by the first observation point and multiplied by 100 . To identify the factors associated with stunting, thinness and overweight, bivariable (unadjusted) logistic regression models were built separately for each of the outcomes. All the independent variables showing a $\mathrm{p}<0.2$ in the unadjusted models were considered in the multivariable logistic regression model. ${ }^{13}$ Only the statistically significant $(p<0.05)$ variable were retained in the final multivariable models presented here.

\section{Patient and public involvement statement}

No patient or public were involved with the development of the research question, designing the study, recruitment of participants, interpretation of the results, and none of them will be involved while disseminating the findings of the paper.

\section{RESULTS}

A total of 1852 adolescent girls (1224 at urban site and 628 at rural site) were enrolled. Nearly two-third of these adolescents were between 15 and 19 years old. Mean age of the participants was $15.6( \pm 2.9 \mathrm{SD})$ (data not presented). Proportion of adolescents from families having a size of more than five members was around 40 per cent. Illiteracy among 15 to 19 years aged adolescents was 14.2 per cent. Both paternal and maternal illiteracy were above 50 per cent. Almost half of the adolescents had a monthly family income of less than US $\$ 100$. Around 40 per cent of the adolescents belonged to lower middle and poorest wealth quintile. Most of the adolescent girls $(48.1 \%)$ use nonsanitary toilet, and majority of them (77.8\%) drink water without boiling. Around 81.5 per cent of the adolescents sought care with some or severe dehydration. Among the enrolled study participants, 40 per cent were stunted, 20 per cent were thin and 3.6 per cent were overweight or obese (see table 2 ).

Figures 1-3: Between 2001 and 2018, the stunting proportion decreased from 49.5 per cent to 24.4 per cent (50.7\% reduction) showing a downward trend line. The proportion of thinness among adolescents was 27.5 per cent in 2001 to 2003 , which gradually decreased to 15.7 per cent in 2015 to 2018 (43\% reduction). Conversely, the uptrend of overweight has been observed with an increase from 1.7 per cent to 7.4 per cent over the study period. Year-wise prevalence of stunting, thinness and overweight are provided in online supplemental file 2.

Table 3: Logistic regression showing associated factors with stunting among 10 to 19 years adolescent girls
Table 2 Characteristics of reported adolescent female participants from Dhaka Hospital (urban) and Matlab Hospital (rural), Bangladesh, 2001 to 2018

\begin{tabular}{|lr|}
\hline Background characteristics & $\begin{array}{l}\text { Overall } \\
\mathbf{n = 1 8 5 2}(\%)\end{array}$ \\
\hline Age distribution & \\
\hline $10-15$ years & $646(34.9)$ \\
$15-19$ years & $1206(65.1)$ \\
\hline
\end{tabular}

\section{Family size}

$\begin{array}{lr}\text { Number of family members }>5 & 738(39.8) \\ \text { Number of family members } \leq 5 & 1114(60.2) \\ \text { Self-education for patients (for }>15 \text { years age) } & \\ \text { No formal education } & 177(14.2) \\ \text { Primary } & 316(25.4) \\ \text { Secondary } & 550(44.2) \\ \text { Higher/above } & 202(16.2)\end{array}$

Father's education

$\begin{array}{lr}\text { No formal education } & 983(53.1) \\ \text { Primary } & 383(20.7) \\ \text { Secondary } & 276(14.9) \\ \text { Higher secondary or above } & 208(11.2) \\ \text { Mother's education } & \\ \text { No formal education } & 1120(60.5) \\ \text { Primary } & 407(22.0) \\ \text { Secondary } & 236(12.7)\end{array}$

Higher secondary or above $\quad 88(4.8)$

Wealth Index

Poorest

$400(21.6)$

Lower middle $341(18.4)$

Middle $356(19.2)$

Upper middle

$387(20.9)$

Richest 368 (19.9)

Monthly family income

Income $\leq$ US $\$ 100$

$910(49.1)$

Income $>$ US $\$ 100$ $942(50.9)$

$\begin{array}{ll}\text { Sanitation } & \\ \text { Use non-sanitary toilet } & 891(48.1) \\ \text { Use sanitary toilet } & 961(51.9)\end{array}$

Water

Use unboiled drinking water

1440 (77.8)

Use boiled drinking water $412(22.2)$

Duration of diarrhoea before arrival

More than 1 day

$661(35.7)$

Duration of hospital stay $>24$ hours $485(26.3)$

Stool contents

Presence of mucus or blood or both $167(9)$

Diarrhoea in last 1 month $3(0.2)$

Continued 


\begin{tabular}{lc}
\hline Table 2 Continued & \\
\hline Background characteristics & $\begin{array}{l}\text { Overall } \\
\mathbf{n}=1852(\%)\end{array}$ \\
\hline \multicolumn{1}{c}{ Morbidity in last 14 days } & $479(25.9)$ \\
Dehydration & \\
$\quad$ Some/severe & $1509(81.5)$ \\
Malnutrition & \\
\hline Stunting & $716(40.5)$ \\
Thinness & $348(19.7)$ \\
Overweight & $63(3.6)$ \\
\hline
\end{tabular}

reporting to the Dhaka Hospital (urban) and Matlab Hospital (rural), Bangladesh, 2001 to 2018.

Figures 1-3: Between 2001 and 2018, the stunting proportion decreased from 49.5 per cent to 24.4 per cent (50.7\% reduction) showing a downward trend line. The proportion of thinness among adolescents was 27.5 per cent in 2001 to 2003, which gradually decreased to 15.7 per cent in 2015 to 2018 (43\% reduction). Conversely, the uptrend of overweight has been observed with an increase from 1.7 per cent to 7.4 per cent over the study period. Year-wise prevalence of stunting, thinness and overweight are provided in online supplemental file 2.

During 2001 to 2018, illiteracy of the participants aged 15 years and more, maternal and paternal illiteracy and monthly family income less than US $\$ 100$, poorest wealth quintile, use of non-sanitary toilet and unboiled drinking water were significantly associated with stunting. Multivariable logistic regression showed association between illiteracy (adjusted OR (aOR) 2.39, 95\% CI (1.68 to 3.39), $\mathrm{p}<0.001$ ), monthly family income of less than US $\$ 100$ (aOR $1.54,95 \%$ CI $(1.25$ to 1.90$), \mathrm{p}<0.001)$ and family belonging to poorest wealth quintile (aOR $1.45,95 \% \mathrm{CI}$ (1.13 to 1.87$), \mathrm{p}=0.004)$ remained significantly associated with stunting (table 3 ).

As for thinness, in the bivariate analysis, we found that older participants (aged 15-19 years), monthly family

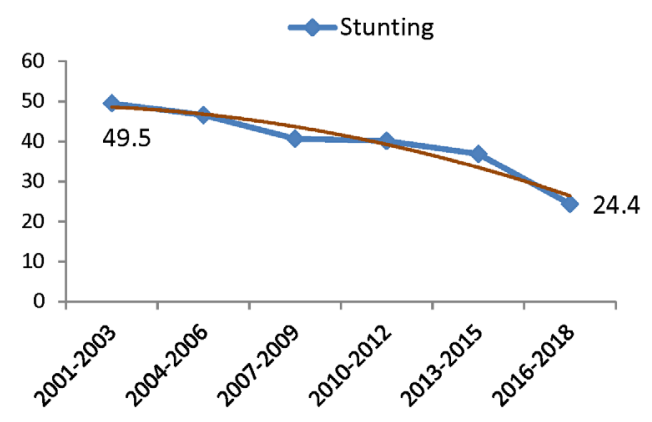

Figure 1 Changing trend of stunting among 10 to 19 years old adolescent girls reporting to the Dhaka Hospital (urban) and Matlab Hospital (rural) of the International Centre for Diarrhoeal Disease Research, Bangladesh (2001-2018).

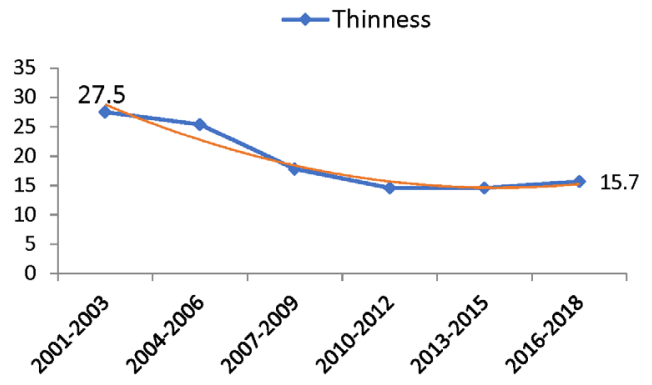

Figure 2 Changing trend of thinness among 10 to 19 years adolescent girls reporting to the Dhaka Hospital (urban) and Matlab Hospital (rural) of the International Centre for Diarrhoeal Disease Research, Bangladesh (2001-2018).

income less than US $\$ 100$, poorest wealth quintile, use of non-sanitary toilet and use of unboiled drinking water showed positive association during the same period. Participants who were hospitalised for more than 24 hours, and those who reported to the rural hospital were significantly associated with thinness. In the multivariable regression model, we found that older adolescents (aOR 2.69, 95\% CI (2.10 to 3.45), $\mathrm{p}<0.001$ ) and monthly family income less than US $\$ 100$ (aOR 1.44, 95\% CI (1.09 to 1.89 ), $\mathrm{p}=0.009$ ) were significantly associated with thinness. Rural participants were 1.71 times at higher risk of thinness than the urban participants. The odds of thinness were 1.52 times higher who were admitted in the hospital for more than 24 hours (aOR 1.52, 95\% CI (1.16 to 1.98$), \mathrm{p}<0.002$ ) (table 4 ).

Table 5: Families having income more than US $\$ 100$ were three times more likely to become overweight (aOR $3.00,95 \%$ CI ( 1.46 to 6.15 ), $\mathrm{p}=0.003$ ). The duration of diarrhoea was found to be significantly associated with overweight (aOR 1.96, 95\% CI (1.17 to 3.29), $\mathrm{p}=0.011$ ). Like thinness, rural participants were 2.76 times (aOR $2.76,95 \%$ CI (1.33 to 5.73$), \mathrm{p}=0.006$ ) more likely to be overweight than their urban counterparts.

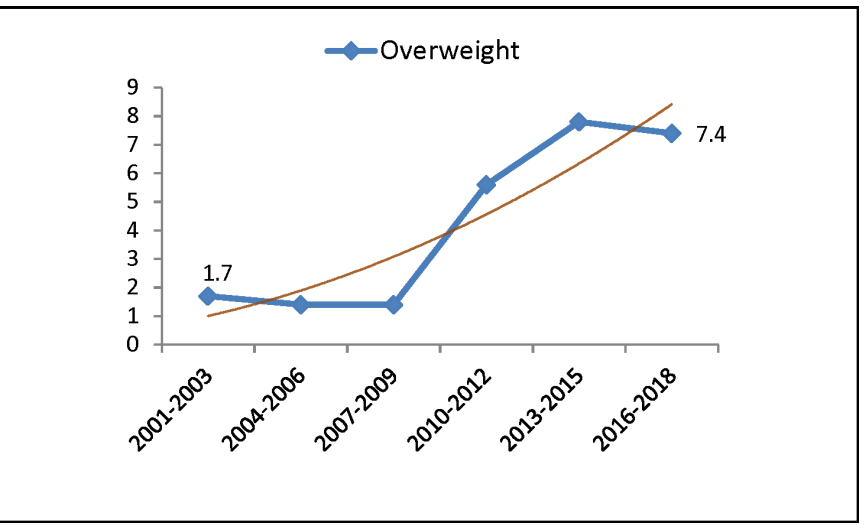

Figure 3 Changing trend of overweight among 10 to 19 years old adolescent girls reporting to the Dhaka Hospital (urban) and Matlab Hospital (rural) of the International Centre for Diarrhoeal Disease Research, Bangladesh (2001-2018). 
Table 3 Logistic regression showing associated factors with stunting among 10 to 19 years adolescent girls reporting to the Dhaka Hospital (urban) and Matlab Hospital (rural), Bangladesh, 2001 to 2018

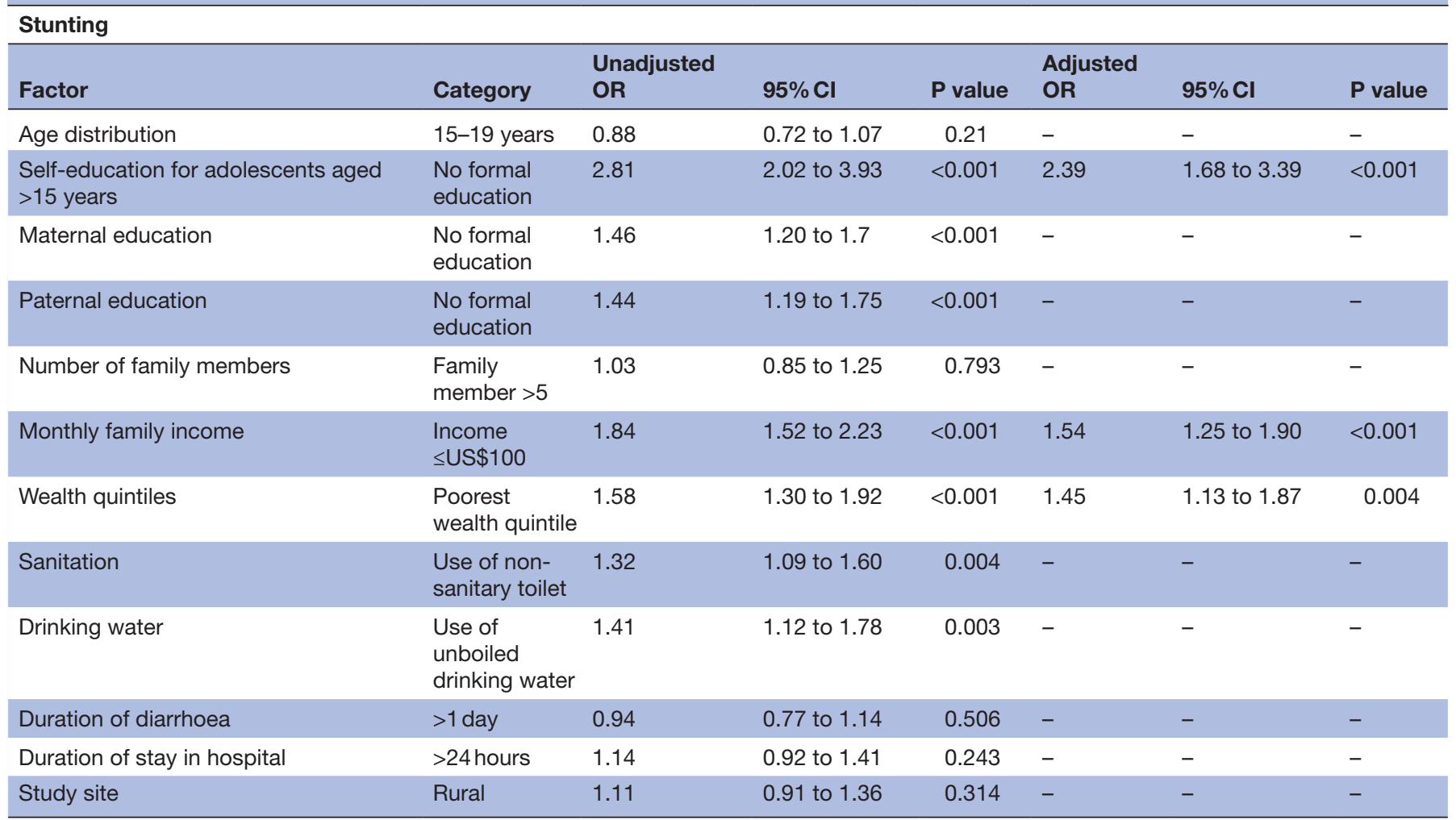

Stunting=Height-for-age $Z$ score $(H A Z)<-2.00 S D$.

\section{DISCUSSION}

In the absence of any recent data regarding the nutritional status of 10 to 19 years old Bangladeshi adolescent female, our secondary analysis of data highlights the extent of changes in nutritional status in terms of stunting, thinness and overweight and its changing trend. We observed significant improvements in stunting, underweight and thinness over the study period. We also analysed the data to report the changing trend in nutritional status of adolescent females from rural and urban Bangladesh, which showed that both stunting $(\mathrm{p}=0.03)$ and thinness $(\mathrm{p}=0.05)$ has decreased over the last two decades while overweight prevalence has increased over the time $(p<0.001)$. According to BDHS data, undernourishment has decreased from 34 per cent to 19 per cent that is a 44 per cent reduction which is similar to our findings $(43 \%)$. Overweight and obesity has increased from 9 per cent in 2004 to 24 per cent in $2014,{ }^{11}$ which is much higher than our observations.

The reason might be due to the different tools used to diagnose thinness and overweight. While BDHS used BMI $\left(\mathrm{kg} / \mathrm{m}^{2}\right)$, we used the more accurate BMI Z score, relative weight measures adjusted for adolescent age and sex to determine their nutritional status. ${ }^{11}$ Identified factors associated with stunting $(\mathrm{p}=0.003)$ and thinness $(\mathrm{p}=0.001)$ were unboiled water source of drinking water. A study conducted in North Ethiopia among adolescent school girls reported similar findings. ${ }^{14}$ Use of non-sanitary toilet was associated with stunting $(\mathrm{p}=0.004)$ and thinness $(\mathrm{p}<0.001)$. This is due to household poverty and poor access to improved sanitation facilities that are still low in Bangladesh, around 61 per cent. ${ }^{15}$

Our study observed that the overall burden of stunting in adolescent girls living in both urban and rural areas were similar, respectively. One study conducted on adolescent female factory workers aged 14 to 19 years back in 2005 revealed that, the prevalence of stunting defined as height for age below $3^{\text {rd }}$ percentile of National Center for Health Statistics growth reference values defined by WHO was not comparable with our findings, 65 per cent compared with our observation of 40.5 per cent. ${ }^{16}$ This difference in observation may be due to several reasons; improved SES, better access to healthcare and enhanced literacy. A Study in Khagrachari District, tribal living in the hilly area in Bangladesh showed that 33.3 per cent of adolescent girls were severely stunted. ${ }^{17}$

Following multivariable analysis with logistic regression, low self education ( $\mathrm{OR}=2.39$; $95 \%$ CI (1.68 to 3.39); $\mathrm{p}<0.001)$ and monthly family income of less than US $\$ 100$ $(\mathrm{OR}=1.54 ; 95 \%$ CI $(1.25$ to 1.90$)$; $\mathrm{p}<0.001)$ were associated with stunting. Although between 2014 and 2017, the proportion of women aged 15 to 49 years who completed secondary education increased from 14 per cent to 17 per cent $^{18}$ still we have 14 per cent of the adolescent girls with no formal education. Encouraging female education may improve healthcare-seeking behaviour and the better use 
Table 4 Logistic regression showing associated factors with thinness among 10 to 19 years adolescent girls reporting to the Dhaka Hospital (urban) and Matlab Hospital (rural), Bangladesh, 2001 to 2018

\begin{tabular}{|c|c|c|c|c|c|c|c|}
\hline \multicolumn{8}{|l|}{ Thinness } \\
\hline Factor & Category & $\begin{array}{l}\text { Unadjusted } \\
\text { OR }\end{array}$ & $95 \% \mathrm{Cl}$ & $P$ value & $\begin{array}{l}\text { Adjusted } \\
\text { OR }\end{array}$ & $95 \% \mathrm{Cl}$ & $P$ value \\
\hline Age distribution & $15-19$ years & 2.87 & 2.26 to 3.64 & $<0.001$ & 2.69 & 2.10 to 3.45 & $<0.001$ \\
\hline $\begin{array}{l}\text { Self-education for adolescents aged }>15 \\
\text { years }\end{array}$ & $\begin{array}{l}\text { No formal } \\
\text { education }\end{array}$ & 1.26 & 0.86 to 1.85 & 0.238 & - & - & - \\
\hline Maternal education & $\begin{array}{l}\text { No formal } \\
\text { education }\end{array}$ & 0.81 & 0.64 to 1.03 & 0.085 & - & - & - \\
\hline Paternal education & $\begin{array}{l}\text { No formal } \\
\text { education }\end{array}$ & 1.01 & 0.80 to 1.28 & 0.931 & - & - & - \\
\hline Number of family members & $\begin{array}{l}\text { Family } \\
\text { member }>5\end{array}$ & 1.15 & 0.91 to 1.46 & 0.256 & - & - & - \\
\hline Monthly family income & $\begin{array}{l}\text { Income } \\
\leq \text { US } \$ 100\end{array}$ & 1.6 & 1.26 to 2.03 & $<0.001$ & 1.44 & 1.09 to 1.89 & 0.009 \\
\hline Wealth quintiles & $\begin{array}{l}\text { Poorest } \\
\text { wealth quintile }\end{array}$ & 1.98 & 1.54 to 2.55 & $<0.001$ & - & - & - \\
\hline Sanitation & $\begin{array}{l}\text { Use of non- } \\
\text { sanitary toilet }\end{array}$ & 1.77 & 1.39 to 2.24 & $<0.001$ & - & - & - \\
\hline Drinking water & $\begin{array}{l}\text { Use of } \\
\text { unboiled } \\
\text { drinking water }\end{array}$ & 1.66 & 1.22 to 2.25 & 0.001 & - & - & - \\
\hline Duration of diarrhoea & $>1$ day & 0.89 & 0.70 to 1.15 & 0.398 & - & - & - \\
\hline Duration of stay in hospital & $>24$ hours & 1.72 & 1.13 to 2.22 & $<0.001$ & 1.52 & 1.16 to 1.98 & 0.002 \\
\hline Study site & Rural & 2.07 & 1.63 to 2.64 & $<0.001$ & 1.71 & 1.23 to 2.38 & 0.001 \\
\hline
\end{tabular}

Thinness=Body Mass Index-for-age Z score (BAZ) $<-2.00 S D$.

of health services and ultimately reduce stunting and its consequences. Across the population, in 2014, children in the poorest wealth quintile were 2.5 times more likely to be stunted. ${ }^{19}$ We have also found poorest wealth quintile $(\mathrm{OR}=1.45 ; 95 \%$ CI $(1.13$ to 1.87$) ; \mathrm{p}=0.004)$, was the major contributory factor to stunting. Alam et al analysed the data from the National Nutrition Programme 2004 and observed thinness among the rural adolescent girls and observed 26 per cent of the study population was thin, which is exactly similar to our observation $(25.6 \%)$ in the year 2005. ${ }^{20}$ Our analysis compared undernourished adolescent girls living in urban and rural areas. The odds of thinness (OR=1.71; 95\% CI (1.23 to 2.38); $\mathrm{p}=0.001)$ and overweight $(\mathrm{OR}=2.76 ; 95 \%$ CI (1.33 to $5.73) ; \mathrm{p}=0.006$ ) were higher among the adolescent girls residing in rural area compared with urban area. This may be due to differentials in the household economy and adolescent literacy between rural and urban areas, still remaining potential challenges to development. ${ }^{21}$ The finding was opposite to what Akhter et al reported in a study back in 2013. They more often found severe thinness among urban adolescents than their rural counterparts. The reason behind this may be due to the different characteristics of the study population. While our study analysed data obtained from hospital attending patients, Akhter $e t a l^{22}$ conducted the study among adolescents from low-income and middle-income families in urban and rural settings. People living in low resource setting in urban areas or slums are generally deprived of essential healthcare. The odds of thinness were 2.69 times higher among adolescent girls in the late adolescent stage than adolescent girls in the early adolescent stage $(\mathrm{OR}=2.69 ; 95 \%$ CI $(2.10$ to 3.45$) ; \mathrm{p}<0.001)$. However, thinness was reported more often in early adolescents by the studies conducted among adolescent school girls in North Ethiopia and India. ${ }^{1423}$ This might be due to the increased growth spurt with a sudden increase of height during the early stage of adolescence compared with late adolescence.

Protein, iron and calcium are also crucial for growth spurt and skeletal development in adolescence. Sixty per cent and more of school girls aged 10 to 16 years in Dhaka city (urban site) consume protein, iron and calcium less than 75 per cent of the recommended daily allowance for age. ${ }^{22}$ Besides, in Bangladesh, 54 per cent of women of reproductive age (10-49 years old) consume inadequately diverse diets (of fewer than five food groups). ${ }^{24}$

The global prevalence of obesity nearly tripled between 1975 and 2016. Overweight and obesity are linked to more deaths worldwide than underweight. ${ }^{25}$ Studies indicated an increasing trend in childhood obesity over time among Bangladeshi children. ${ }^{26}$ We also looked at the extent of overnutrition among this age group, and we found that 3.6 per cent of the participants were overweight defined as BMI Z score being more than +2.00 . A study conducted in China reported 8.3 per cent 
Table 5 Logistic regression showing associated factors with overweight among 10 to 19 years adolescent girls reporting to the Dhaka Hospital (urban) and Matlab Hospital (rural), Bangladesh, 2001 to 2018

\begin{tabular}{|c|c|c|c|c|c|c|c|}
\hline \multicolumn{8}{|l|}{ Overweight } \\
\hline Factor & Category & $\begin{array}{l}\text { Unadjusted } \\
\text { OR }\end{array}$ & $95 \% \mathrm{CI}$ & $P$ value & $\begin{array}{l}\text { Adjusted } \\
\text { OR }\end{array}$ & $95 \% \mathrm{Cl}$ & $P$ value \\
\hline $\begin{array}{l}\text { Self-education for adolescents aged } \\
>15 \text { years }\end{array}$ & $\begin{array}{l}\text { No formal } \\
\text { education }\end{array}$ & 0.48 & 0.15 to 1.55 & 0.219 & - & - & - \\
\hline Maternal education & $\begin{array}{l}\text { No formal } \\
\text { education }\end{array}$ & 0.28 & 0.17 to 0.49 & $<0.001$ & - & - & - \\
\hline Number of family members & $\begin{array}{l}\text { Family } \\
\text { member }>5\end{array}$ & 0.86 & 0.51 to 1.45 & 0.581 & - & - & - \\
\hline Monthly family income & $\begin{array}{l}\text { Income } \\
>\text { US } \$ 100\end{array}$ & 5.53 & 2.79 to 10.94 & $<0.001$ & 3 & 1.46 to 6.15 & 0.003 \\
\hline Drinking water & $\begin{array}{l}\text { Use of } \\
\text { unboiled } \\
\text { drinking water }\end{array}$ & 0.69 & 0.40 to 1.20 & 0.191 & - & - & - \\
\hline Duration of diarrhoea & $>1$ day & 2.22 & 1.34 to 3.68 & 0.002 & 1.96 & 1.17 to 3.29 & 0.011 \\
\hline Duration of stay in hospital & $>24$ hours & 0.53 & 0.26 to 1.05 & 0.068 & - & - & - \\
\hline Study site & Rural & 2.07 & 1.63 to 2.64 & $<0.001$ & 2.76 & 1.33 to 5.73 & 0.006 \\
\hline
\end{tabular}

Overweight=Body Mass Index-for-age Z score (BAZ) >+1.00 SD.

prevalence of overweight and obesity among adolescents which is much higher than our findings. ${ }^{27}$ Children and adolescents in low-income and middle-income countries are consuming energy-dense foods that are high in fat and sugars; although these foods tend to be cheaper, they are low in nutrient quality. The increasing prevalence of obesity among adolescents worldwide can be explained by widespread nutrition transitions to lipid-rich diets and a decrease in physical activity. ${ }^{28}$ Logistic regression showed an increase in higher family income was significantly associated with higher odds of being overweight (3.00, 95\% CI (1.46 to 6.15), $\mathrm{p}=0.003)$. Similar findings were reported in another study conducted by Rahman et $a .^{29}$ Kamal et al analysed data from BDHS 2011, among 16273 participants aged 15 to 49 years, 2.9 per cent of the participants were obese, ${ }^{30}$ which is similar to our findings. A study conducted by Kurshed et al in 2010 indicated that prevalence of overweight determined as BMI $>25.00$ among adolescent females aged 10 to 18 years was 4.6 per cent. ${ }^{31}$ In the year 2011, Corsi et al reported that in Bangladesh the nationwide prevalence of overweight among women of 15 to 19 years age was $1.6 \%$ which was found to be lower than our observation. ${ }^{32}$ This might be explained by the time differential in data collection. As the data was collected back in 2004 during demographic and health survey, we can expect a steady rise in prevalence of overweight among the adolescent girls. In 2013, 23 per cent of women were overweight or obese (BMI at or above $25 \mathrm{~kg} / \mathrm{m}^{2}$ ), an increase of 6 percentage points from 2011 in rural China. ${ }^{33}$ One interesting finding is that duration of diarrhoea was associated with overweight (aOR 1.96, 95\% CI (1.17 to 3.29), $\mathrm{p}=0.011$ ). Similar result was reported in a National Health and Nutrition Examination Survey among US adults, found positive association between obesity and chronic diarrhoea. ${ }^{34} \mathrm{~A}$ birth cohort study conducted among 980 young adults in Dunedin, New Zealand, also found positive association between increased BMI and diarrhoea. ${ }^{35}$ Literature also suggests that up to 8.5 per cent of obese and 11.5 per cent of severely obese individuals had chronic diarrhoea, compared with 4.5 per cent of normal-weight individuals. ${ }^{36}$ This might be explained as obese participants are more likely to ingest excess amounts of poorly absorbed sugars, which can promote osmotic diarrhoea. ${ }^{37}$ The findings from the present study were comparable with the global and the Asian context. ${ }^{38} 39$

One of the limitations of the study was that data were facility based as a result only those who sought care with sickness have been included in the study. Information gathered was based on recall of the participants; thus subjected to bias. Those who were not included in the sample and those cases that occurred at the community and did not report to the facility have not been studied. Additionally, healthy individuals had no space to be included in analysable sample. Thus, results may not be generalisable. However, capturing information over a 
longer period and using unbiassed systematic sampling were the strengths of the study.

\section{CONCLUSION}

Our present data have reflected both successes and challenges. Although stunting and thinness among adolescent girls are on the decline, overweight is increasing, which is alarming. We have identified a few risk-factors and keyfactors: level of education, family income, wealth quintile, rural participants and sanitation. Improvements of nutritional status of adolescent girls could be an important step towards breaking the vicious cycle of intergenerational malnutrition. A sound national policy should be developed on adolescent nutrition. Nutrition intervention should include nutrition education for adolescents and should be accompanied by fully costed plans that include estimates of the resources needed to implement the interventions. NGOs (non-governmental organisations) and other relevant actors should ensure rural settlements are integrated into available nutrition services. We, therefore, recommend a scaling up of nutrition intervention to address the double burden of malnutrition.

Acknowledgements This research study was supported by core donors who provide unrestricted support to icddr,b for its operations and research. Current donors providing unrestricted support include: Government of the People's Republic of Bangladesh; the Department of Foreign Affairs, Global Affairs Canada (GAC); Swedish International Development Cooperation Agency (Sida) and the Department for International Development (UK Aid). We gratefully acknowledge these donors for their support and commitment to icddr,b's research efforts. Most of all, we thank the participants who have participated in the study.

Contributors IM, AF and MIH formulated the research question. IM, TA, AF and MIH designed the methodology. All helped in literature search. IM, MH, SHK, SD, AF and $\mathrm{MIH}$ contributed to the data analyses and interpretation. IM and $\mathrm{MH}$ wrote the manuscript. TA, AF, MIH and SD reviewed the manuscript. All the authors approved the final version of the draft.

Funding The authors have not declared a specific grant for this research from any funding agency in the public, commercial or not-for-profit sectors.

Competing interests None declared.

Patient consent for publication Not required.

Ethics approval The DDSS has been approved by the Research Review Committee (RRC) and Ethical Review Committee (ERC) at the icddr,b (Approval no. 1992-011). At admission, verbal consent is taken from caregivers or guardians on behalf of children or adult patients following the hospital policy. Consenting individuals are assured about the non-disclosure of personal health information and informed that data will be used to improve patient care activities and facilitate research that may be conveyed by publication; subjects may refuse participation without compromise to patient care. The ERC of icddr,b has approved this verbal consent procedure and is satisfied with the voluntary participation, maintenance of the rights of the participants and confidential handling of personal information by the hospital physicians.

Provenance and peer review Not commissioned; externally peer reviewed.

Data availability statement Data are available upon reasonable request. The data were retrieved from Diarrhoeal Disease Surveillance System (DDSS) of International Centre for Diarrhoeal Disease Research, Bangladesh (icddr, b). The encrypted data are kept at icddr,b and can be made available on reasonable request if permitted by the above mentioned health authorities.

Supplemental material This content has been supplied by the author(s). It has not been vetted by BMJ Publishing Group Limited (BMJ) and may not have been peer-reviewed. Any opinions or recommendations discussed are solely those of the author(s) and are not endorsed by BMJ. BMJ disclaims all liability and responsibility arising from any reliance placed on the content. Where the content includes any translated material, BMJ does not warrant the accuracy and reliability of the translations (including but not limited to local regulations, clinical guidelines, terminology, drug names and drug dosages), and is not responsible for any error and/or omissions arising from translation and adaptation or otherwise.

Open access This is an open access article distributed in accordance with the Creative Commons Attribution Non Commercial (CC BY-NC 4.0) license, which permits others to distribute, remix, adapt, build upon this work non-commercially, and license their derivative works on different terms, provided the original work is properly cited, appropriate credit is given, any changes made indicated, and the use is non-commercial. See: http://creativecommons.org/licenses/by-nc/4.0/.

\section{ORCID iDs}

Ishita Mostafa http://orcid.org/0000-0003-4297-8245

Subhasish Das http://orcid.org/0000-0002-7852-6569

Tahmeed Ahmed http://orcid.org/0000-0002-4607-7439

\section{REFERENCES}

1 Tumilowicz A, Beal T, Neufeld LM, et al. Perspective: challenges in use of adolescent anthropometry for understanding the burden of malnutrition. Adv Nutr 2019;10:563-75.

2 Melaku YA, Zello GA, Gill TK, et al. Prevalence and factors associated with stunting and thinness among adolescent students in northern Ethiopia: a comparison to World Health organization standards. Arch Public Health 2015;73:44.

3 World Health Organization. South-East Asia. adolescent health. Available: https://www.who.int/southeastasia/health-topics/ adolescent-health

4 Christian P, Smith ER. Adolescent undernutrition: global burden, physiology, and nutritional risks. Ann Nutr Metab 2018;72:316-28.

5 Nguyen PH, Sanghvi T, Tran LM, et al. The nutrition and health risks faced by pregnant adolescents: insights from a cross-sectional study in Bangladesh. PLoS One 2017;12:e0178878.

6 Rah JH, Christian P, Shamim AA, et al. Pregnancy and lactation hinder growth and nutritional status of adolescent girls in rural Bangladesh. J Nutr 2008;138:1505-11.

7 Kolčić I. Double burden of malnutrition: a silent driver of double burden of disease in low- and middle-income countries. J Glob Health 2012;2.

8 Khara T, Mates E. Adolescent nutrition policy and programming in SUN+ countries, 2015.

9 Jaacks LM, Slining MM, Popkin BM. Recent trends in the prevalence of under- and overweight among adolescent girls in low- and middleincome countries. Pediatr Obes 2015;10:428-35.

10 Bangladesh Bureau of Statistics, Ministry of Planning, Dhaka. Population census, 2011.

11 Ministry of Health and Family Welfare. Bangladesh demographic and health survey. 328, 2014.

12 Onyango AW, De Onis M. Traning course on child growth assessment: who child growth standards. Geneva: WHO, 2008.

13 Lemeshow S, Sturdivant RX, Hosmer DW. Applied logistic regression. John Wiley \& Sons, 2013.

14 Gebregyorgis T, Tadesse T, Atenafu A. Prevalence of thinness and stunting and associated factors among adolescent school girls in Adwa town, North Ethiopia. Int J Food Sci 2016;2016:1-8.

15 UNICEF and World Health Organization. Progress on sanitation and drinking water - 2015 update and MDG assessment. Genvea: WHO, 2015.

16 Khan MR, Ahmed F, status P. Physical status, nutrient intake and dietary pattern of adolescent female factory workers in urban Bangladesh. Asia Pac J Clin Nutr 2005;14:19.

17 Hossain GMM, Sarwar MT, Rahman MH. A study on nutritional status of the adolescent girls at Khagrachhari district in Chittagong Hill tracts, Bangladesh. American Journal of Life Sciences 2013;1:278-82.

18 Ministry of Health and Family Welfare. Bangladesh demographic and health survey. 2017-2018.

19 Rabbani A, Khan A, Yusuf S, et al. Trends and determinants of inequities in childhood stunting in Bangladesh from 1996/7 to 2014. Int J Equity Health 2016;15:186.

20 Alam N, Roy SK, Ahmed T, et al. Nutritional status, dietary intake, and relevant knowledge of adolescent girls in rural Bangladesh. $J$ Health Popul Nutr 2010;28:86.

21 Bangladesh Ministry of Finance. Bangladesh economic review 2014: socio-economic indicators of Bangladesh. Dhaka, Bangladesh: Government of Bangladesh, 2014.

22 Akhter N, Sondhya FY. Nutritional status of adolescents in Bangladesh: comparison of severe thinness status of a low-income 
family's adolescents between urban and rural Bangladesh. J Educ Health Promot 2013;2:27.

23 Baliga S, Mallapur M, Naik V. Nutritional status of adolescent girls residing in rural area: a community-based cross-sectional study. $J$ Sci Soc 2014:41:22

24 Sinharoy SS, Waid JL, Haardörfer R, et al. Women's dietary diversity in rural Bangladesh: pathways through women's empowerment. Matern Child Nutr 2018;14:e12489.

25 World Heath Organization. Overweight and obesity. key facts, 2020.

26 Rahman S, Islam MT, Alam DS. Obesity and overweight in Bangladeshi children and adolescents: a scoping review. BMC Public Health 2014;14:70.

$27 \mathrm{He}$ Y, Pan A, Yang Y, et al. Prevalence of underweight, overweight, and obesity among reproductive-age women and adolescent girls in rural China. Am J Public Health 2016;106:2103-10.

28 Harding KL, Aguayo VM, Webb P. Trends and correlates of overweight among pre-school age children, adolescent girls, and adult women in South Asia: an analysis of data from twelve national surveys in six countries over twenty years. Nutrients 2019;11:1899.

29 Rahman SMM, Akter BMD. Siddiqui MZA: prevalence of childhood obesity in Dhaka City. Mymensingh Med J 1998;7:3-6.

30 Kamal SMM, Hassan CH, Alam GM. Dual burden of underweight and overweight among women in Bangladesh: patterns, prevalence, and sociodemographic correlates. J Health Popul Nutr 2015;33:92.

31 Kurshed AAM, Rana MM, Khan S, et al. Dietary intake, physical activities and nutritional status of adolescent girls in an urban population of Bangladesh. Ibrahim Med Col J 2010;4:78-82.
32 Corsi DJ, Kyu HH, Subramanian SV. Socioeconomic and geographic patterning of under- and overnutrition among women in Bangladesh. J Nutr 2011;141:631-8.

33 Hruby A, Hu FB. The epidemiology of obesity: a big picture. Pharmacoeconomics 2015;33:673-89.

34 Shin A, Xu H, Imperiale TF. Associations of chronic diarrhoea with non-alcoholic fatty liver disease and obesity-related disorders among US adults. BMJ Open Gastroenterol 2019;6:e000322.

35 Talley NJ, Howell S, Poulton R. Obesity and chronic gastrointestinal tract symptoms in young adults: a birth cohort study. $A m \mathrm{~J}$ Gastroenterol 2004;99:1807-14.

36 Ballou S, Singh P, Rangan V, et al. Obesity is associated with significantly increased risk for diarrhoea after controlling for demographic, dietary and medical factors: a cross-sectional analysis of the 2009-2010 National health and nutrition examination survey. Aliment Pharmacol Ther 2019;50:1019-24.

$37 \mathrm{Ho} \mathrm{W}$, Spiegel BMR. The relationship between obesity and functional gastrointestinal disorders: causation, association, or neither? Gastroenterol Hepatol 2008;4:572.

38 Gupta N, Goel K, Shah P, et al. Childhood obesity in developing countries: epidemiology, determinants, and prevention. Endocr Rev 2012;33:48-70.

39 Global Nutrition Report. The global burden of malnutrition at a glance, 2020. Available: https://globalnutritionreport.org/resources/ nutrition-profiles/\#overview 